\title{
Comunicación y democracia en el entorno digital ${ }^{1}$
}

Ramón Zallo Elguezabal Universidad del País Vasco-Euskal Herriko Unibertsitatea

\section{Palabras clave}

Era digital, comunicación analógica, cultura digital, democracia relacional, crisis democrática, ciberdemocracia.

\section{Resumen en castellano}

Desde una mirada holística, crítica y constructiva, se analizan los lazos de la comunicación y la cultura con la democracia de nuestro tiempo. Para ello se describen algunos cambios sistémicos, incluida la crisis democrática, y que configuran el contexto para cualquier actividad. Se apuntan algunos problemas de la comunicación en lo que es una época de transición de la cultura y comunicación analógicas a la cultura y comunicación digitales, se comparan los rasgos ya presentes y algunas tendencias en la era digital. Respecto a la democracia, se diagnostican algunas problemáticas y se sugiere la utilidad de algunas herramientas comunicativas para el paso de una democracia representativa a una democracia relacional. Un impulso de la democratización significa también repensar un modelo de comunicación acorde.

1 Este texto es una versión de la conferencia pronunciada en la Universitat Jaume I (Castelló) para inaugurar al IV Congreso de ULEPICC- España (Unión Latina de Economía Política de la Información, la Comunicación y la Cultura), el 15 de noviembre de 2012 . 


\title{
Communication and democracy in the digital context
}

\section{Keywords}

Digital era, analogue communication, digital culture, relational democracy, democratic crisis, ciberdemocracy.

\begin{abstract}
From a holistic, critical and constructive point of view, we analyze the bonds of communication and culture to the democracy of our time. We, therefore, describe some systemic changes, including the crisis of democracy, that set the context for any activity. We point out some of the problems of communication in what is a time of transition from an analogue communication culture to a digital culture and Communications system, we compare the features already present and some trends in the digital age. Regarding democracy, we diagnose some of the problems and suggest the usefulness of some communication tools to go from a representative democracy to a relational democracy. An impulse of democratization also means rethinking a suitable communication model.
\end{abstract}

\begin{abstract}
Autor
Ramón Zallo Elguezabal [ramon.zallo@ehu.es] es Catedrático de Comunicación Audiovisual y Publicidad en la Universidad del País Vasco-Euskal Herriko Unibertsitatea y presidente de la sección española de la Unión Latina de Economía Política de la Información, la Comunicación y la Cultura (ULEPICC) España. Ha publicado, como autor o coordinador, Economía de la comunicación y la cultura (1982), El mercado de la cultura (1992), Industrias y políticas culturales en España y el País Vasco (1995), y Estructuras de la comunicación y de la cultura. Políticas en la era digital (2011), entre otros.
\end{abstract}


Los análisis de la comunicación muchas veces aíslan nuestro campo del cuadro que les da sentido: la sociedad y los cambios que está sufriendo, no solo por las TIC, sino también en lo geopolítico, lo geo-económico y lo estrictamente político, social o cultural. Aquí se reivindica esa visión de conjunto del que es parte, como factor relevante, la propia comunicación.

\section{Un contexto de transiciones a alguna parte}

Vivimos, desconfiados cuando no decepcionados, en un mundo inquietante y contradictorio, de avances y retrocesos, lleno de incertidumbres e inseguridades, y de temor por el futuro de nuestro bienestar y de las jóvenes generaciones. Para enmarcar unos acontecimientos que se escapan a una explicación única parece útil apuntar un cuadro general de contexto.

1. Tras la debacle de los títulos subprime, la crisis de las hipotecas y la entrada en pérdidas multimillonarias de muchas instituciones financieras, e incluso con la quiebra en dominó de algunas muy importantes como Lehman Brothers, se suponía que había que refundar el capitalismo con una nueva regulación global. Así lo demandó Sarkozy en Davos. Se trata de una crisis sistémica -económica, ecológica, cultural y política- así como una crisis financiera producida por el irresponsable sistema bancario del paraíso neoliberal. Pero es más una crisis en el sistema que del sistema, con pocos riesgos de derrumbe por implosión aunque sí de desvertebración e insostenibilidad.

Parecía, ante la indignación social mundial, que el poder político se ponía a la obra de rehabilitar el sistema mediante una profundización democrática y una nueva regulación que impidiera que nada semejante volvería a ocurrir. Lo cierto es que las promesas se quedaron en nada.

Al contrario, y poco después, el sistema financiero mundial causante de la crisis, puso a los sistemas políticos democráticos y los presupuestos públicos a su servicio -excepción hecha de Islandia- mediante la socialización de las pérdidas y al precio del deterioro general del nivel de vida y de una gigantesca redistribución negativa de la renta. Los Estados democráticos, asumiendo políticas neoliberales en la etapa menos propicia para ello, aceptaron una doble dinámica de deterioro del Estado del Bienestar y de renuncia a su misión para la vida buena ciudadana. Un ejemplo. Tuvieron que suicidarse varias personas, plantarse los jueces que a pie de portal han debido ejecutar miles de desahucios en España y una llamada de atención de la Unión Europea (UE) por contar con una legislación hipotecaria que deja en indefensión a los embargados, para que la clase política se haya visto obligada a encarar el tema, y muy parcialmente.

2. El poder de los Estados se está erosionando por la globalización financiera que, desregulada, sigue campando a sus anchas de manera autónoma, con las grandes multinacionales, especialmente los bancos, como poder global confirmado. Las fugas de capitales a paraísos varios son brutales. Se estimaba que en 
2010, de 21 a 32 billones -millones de millones- estaban en cuentas de jurisdicciones offshore (extraterritoriales) bajo reserva y libres de impuestos. En el caso español, la fuga de capitales se estimaba, entre junio de 2011 y el mismo mes de 2012, en un total de 296.000 millones de dólares, lo que equivale al $27 \%$ del PIB de 2011. Una fuga «a gran escala», según el FMI (Expansión, 2012).

3. Paralelamente se produce una remodelación geoeconómica con nuevos actores (BRICS- Brasil, Rusia, India, China y Sudáfrica) y la impotencia de los estados tanto ante los actores supranacionales financieros como ante los países líderes con disponibilidad financiera (como son los casos de China o Alemania) que marcan las políticas al resto. Esa impotencia es patente incluso donde la institucionalización ha avanzado más en la historia, como es el caso de los países de la UE.

Hay así potencias hegemónicas globales o regionales. Las uniones de Estado, como la UE, tienen más peso económico que geopolítico, que sigue reservado a las potencias aunque se haya diluido un tanto el unilateralismo que hemos vivido desde la caída del Muro.

4. Parecía que el capital inmaterial y el I+D+i iban a ser las grandes especializaciones de los países más avanzados en la nueva División Internacional del Trabajo. La realidad de la crisis ha hecho aflorar que no hay capital inmaterial sin industrias y servicios que la sostengan, como ha evidenciado Alemania, y que los países emergentes también cuentan con capacidad de I+D+i. El pinchazo de la burbuja inmobiliaria y la larga alegría en el mercado de valores, en una huida sin fin ni base económica real, así lo han evidenciado. La comunicación y la cultura son parte cualificada de ese capital inmaterial en su doble lectura: un capital real y una expectativa sin confirmación.

5. Se dan sólo ligeros avances en gobernanza mundial, pero más en el plano de los valores morales, principios y leyes, o en estructuras institucionales y de justicia internacionales (Held, 2012: 227) que en los ámbitos propiamente políticos y, ya no digamos en los económicos. Según Beck, «Globalización significa también: ausencia de Estado mundial; más concretamente: sociedad mundial sin Estado mundial y sin gobierno mundial (...) Un capitalismo global desorganizado».

Es más, asistimos a una desgobernanza, con retrocesos como en las aportaciones del $0,7 \%$ del PIB a países en desarrollo o con el incumplimiento de los objetivos de Kyoto del 2006 o de Río y Doha en el 2012. Y no ha sido paliada por organismos como la OMC, FMI o el Banco Mundial, que habiendo sido favorables a las grandes potencias, también tienen pendiente su reestructuración en esta etapa depresiva del capitalismo tardío.

Los bocados al Estado del Bienestar están a la orden del día. El capitalismo se ha desentendido del bienestar y corre riesgos de contestación global.

6. Junto a las instituciones democráticas, y en una dinámica de distribución de poderes políticos, surgen nuevos actores no estatales en el interior de los países. Ahí aparecen dos situaciones. 
Por un lado, se consolidan procesos de descentralización que generan nuevas instituciones más cercanas a la ciudadanía y que, en un momento dado, pueden cuestionar la estructura organizacional del Estado como es el caso de algunas naciones sin Estado en la UE (Escocia, Catalunya, Euskadi) o fuera de ella (Quebec). Para Colomer (2006:173) España es un caso único en Europa de fracaso en la construcción de un gran Estado nacional que perdió su oportunidad en la segunda mitad de los años setenta.

Por otro lado, se produce una desestatización desde la emergencia de múltiples organismos sociales no gubernamentales -con alcance mundial de algunas ONG- y un sinfín de organismos de nuevo cuño que vigilan, monitorean (Keane 2009), chequean a los Estados con detalle y descubren fallas importantes.

Todo ello hace a la ciudadanía muy consciente de la disfuncionalidad y pérdida de legitimidad de las democracias. De hecho, los ciudadanos no quieren ser gobernantes, no quieren mandar; sólo le piden a las instituciones imparcialidad, independencia, justicia y, para ello, que proliferen los controles. Pero esos resortes múltiples de control interno en las sociedades avanzadas tampoco pueden abordar las temáticas claves, y actúan sobre aspectos periféricos, o sobre algunas disfuncionalidades del sistema, como la corrupción o los modos decisionales. Las grandes decisiones están enajenadas y quedan fuera de foco.

7. Paralelamente a esa extensión de la vigilancia social de un amplio sector que transmite al instante alertas sobre parcelas de la vida colectiva, ha aumentado la vigilancia de los poderes sobre la sociedad en busca de orden. Mediante una seguridad preventiva, se pasa de vigilar a los criminales a vigilar a todos los ciudadanos como potenciales criminales. La propia red Twitter se utiliza para la vigilancia, el control y la propaganda. ${ }^{2}$

Si los derechos de privacidad no se regulan adecuadamente, la perspectiva es que vamos a vivir en sociedades de registro y huella con riesgo de amenazas futuras o, en el caso peor, en sociedades de control tipo «Gran Hermano» con interceptación de las comunicaciones. Mattelart decía que los dispositivos de televigilancia planetaria -por ejemplo, la red Echelon- sólo representan la parte emergente del complejo técnicoinformacional con finalidades de orden y control flexible. Así en EE.UU., la Ley FISA (Foreigh Intelligence Surveillance Act) que otorga a las agencias de inteligencia la posibilidad de espiar física y electrónicamente a los ciudadanos de EEUU sin orden judicial, se ha prorrogado por el Senado estadounidense hasta 2017.

Se implanta la Vigilancia en aras a la Seguridad a escala universal, con un carácter de panóptico, y que ya denunciara Michel Foucault. Es la Sociedad de Riesgo convertida en Sociedad de seguridad que sacrifica parcelas crecientes de libertad.

Como se advierte, la información se sitúa, en positivo y en negativo, en el centro de un tipo de Sociedad que ya está aquí.

2 Robert Plant: “Call It Antisocial Media: Even Twitter Has a Dark Side” December 7, 2012 http://blogs.hbr.org/ cs/2012/12/call_it_antisocial_media_even.html 
8. Las democracias son el sistema político más que mayoritario en el mundo y los Estados siguen siendo los agentes centrales de la acción política, a pesar de su adelgazamiento decisorio. Son los detentadores de la soberanía y ejercientes del poder en nombre de sus ciudadanías. Menospreciar su rol sería un gran error porque son también los lugares de planteamiento y resolución de múltiples conflictos. Disponen de la legitimidad de origen en un espacio acotado y respetado por otros. Avanzan, de vez en cuando, en procedimientos en una legitimidad de ejercicio; pero, cada vez más, ven deteriorada la legitimidad de resultados ante la decepción de esas ciudadanías que no ven canalizadas sus problemáticas.

El malestar democrático viene a añadirse al malestar social y obliga a volver a empezar, a resetear el debate sobre la regeneración de la democracia y sobre una solidaridad social que fortalezca el vínculo social.

No es concebible satisfacer a la ciudadanía sin restaurar el rol proactivo de las administraciones públicas en nombre del interés general. Sin embargo, los presupuestos recortados impuestos por la UE, así como los propios de Unión para 2013, y las estrategias regresivas como el desmantelamiento de servicios públicos, incluidos los mediáticos, van en distinta dirección.

Ello indica que la capacidad de reacción no vendrá de los Estados sino de la sociedad civil y será ésta la que los presione para volver a actuar en beneficio ciudadano. Con todo, no es fácil que las iniciativas sociales autónomas -la autoorganización o la desobediencia civil- vayan, más allá de desbordar a las instituciones, a poder reinvertir los procesos. Se requieren, paralelamente, nuevas narrativas alternativas, nuevos liderazgos políticos y avanzar, en claves de alianzas, hacia un bloque hegemónico en sentido gramsciano. Es la conjunción de ambos tipos de elementos -acción y construir un sujeto- la que puede ofrecer salidas alternativas.

9. La posmodernidad y sus miradas han traído algunas confusiones. Se ha dicho que esta es la era del acceso, y es verdad que la gestión racional invita a acceder a los servicios puntualmente (o en streaming en el caso de Internet) en lugar de adquirir complejos sistemas que luego se infrautilizan. Siendo eso verdad, es aun más verdad que la sociedad actual sigue rigiéndose por la propiedad y su acumulación a cualquier precio, y de manera más acentuada que en el pasado en tanto aumenta la desigualdad. Es la base del capitalismo.

La emergencia de micropoderes no avala la idea de que se habría producido ya una distribución del poder real. No se sostiene cuando se constata que 147 grandes corporaciones trasnacionales, especialmente entidades financieras como Goldman Sachs y otras, son los propietarios en red de 43.060 multinacionales que controlan el $40 \%$ de la riqueza de la economía global (Vitali y otros, 2011). El poder se concentra aún más en familias, con nombres y apellidos, que ostentan el peso económico en el mundo.

Que se entramen en redes y afloren macropoderes, de ninguna manera quiere decir que estén en proceso de horizontalización. Más bien se concentran y es- 
conden. Wikileaks les ha servido de aviso. Ni siquiera realizan ya estrategias de relaciones públicas. De la transparencia selectiva han pasado a la opacidad total. Ven mucho más útil esa opacidad, con múltiples cortafuegos, que no estar en el espacio público. Ya contratan menos expertos en comunicación que en ocultación y contrainformación. El oficio de espía suple al de informador. Los candados sobre la información más estratégica de todo tipo se han multiplicado mientras nos enfrascamos como internautas y ciudadanos con la información de segundo nivel.

10. El espacio público se ve ampliado de manera cualitativa con la aparición del ciberhogar. ${ }^{3}$

Es el hogar digital, equipado, interconectado, transmisor -no meramente receptor- y articulado en miríadas de redes que abre un espacio público nuevo no institucional -el ciberespacio- que escapa, en parte, a la gestión de la información y de la opinión pública propia de los media tradicionales. Al hogar digital, y al homo digitalis et mobile, ubicuo con acceso a multi-recursos mediante la banda ancha móvil propia de los smartphones y la interconexión de los sistemas telecomunicativo, informático y televisivo, con entrada continua a plataformas y redes sociales.

La idea de participación democrática se convulsiona. La comunicación crece mucho más rápida que la democracia. Antes el hogar estaba excluido del campo de espacio público y de la generación de opinión pública, ahora es parte importante de su entramado. Deviene espacio público emisor y mediador. Pero el espacio sobre el que puede influir no llega hasta las cuevas de un atrincherado y feliz Ali Babá: el capital financiero.

11. Paralelamente a la reafirmación de la presencia religiosa en el mundo (y su complejidad en Occidente merced a la inmigración) afloran identidades de género, identidades nacionales ocultadas, identidades virtuales y múltiples, con lo que vivimos una era de refundación de los pilares de las sociedades. Es la vuelta a los debates constituyentes básicos en unas democracias tensionadas por los riesgos de desestructuración y/o de xenofobia. Casar con naturalidad y respeto esas identidades es uno de los retos de las sociedades interculturales.

A modo de primera conclusión. Sólo desde un cuadro general cabe reflexionar, críticamente y en positivo, sobre comunicación y democracia. Un enfoque alejado tanto de los cánticos gloriosos a la supuesta función salvadora de la tecnología o de las redes (herramientas de uso múltiple y vector sobre el que se construye el capitalismo digital) como de la mitificación de unas democracias, hoy de mera rotación de gobiernos electos que se han desentendido de la ciudadanía y se niegan a embridar los poderes ocultos.

3 Aprovechando la inmensa cantidad de datos que se almacenan y con un registro de usuarios interesados para identificar tendencias y calibrar los mensajes, Barak Obama apuntilló su campaña en la Red dirigiéndose hacia cada uno de los presuntos votantes. Durante año y medio un centenar de desarrolladores web, ingenieros, analistas de datos y antiguos hackers informáticos trabajaron en la sexta planta de un rascacielos de Chicago para confeccionar la estrategia digital de la campaña (http://www.finanzas.com/noticias/usa/20121104/frenesi-final-cuartel-general-1602049.html). 


\section{La comunicación analógica, superada pero no apagada}

12. El sistema mediático convencional (prensa, radio y televisión básicamente), al que habría que agregar los medios de comunicación de la Red, no ha desaparecido ni mucho menos.

Tiene muchas funciones sociales ${ }^{4}$. Asimismo es el espacio público en el que los agentes se confrontan en busca de legitimidad ante la opinión pública (ente abstracto que se gestiona preferentemente y, en teoría, desde los media) y fomenta, como sistema de control social que también es, la «mayoría silenciosa» en la perspectiva de la «espiral del silencio» (Neumann, 1995).

A pesar de Internet, o mejor, además de Internet, la comunicación sigue en el corazón de la regulación social: mantiene agendas que reflejan el espacio público de preocupaciones, mientras se desdibuja el rol del sistema político, salvo en los momentos de grandes decisiones. La TV sigue siendo el lugar preferente donde se informan las mayorías: 46\%, según el CIS, seguido de Internet -ya en segundo lugar- con el $20 \%$, los periódicos con el $19 \%$ y la radio el $13 \% .^{5}$ El balance en el caso español no es positivo. ${ }^{6}$

Con una visión más dinámica, se constata el desplazamiento de los usos hacia las pantallas (TV, PC, smartphone, tableta) a costa de la prensa convencional, la radio y las revistas. La TV crece tanto en el visionado tradicional de televisor como en el resto de pantallas, en versiones en directo o en catchup TV (fuera de programación). Esas pantallas operan como ventanas adaptadas y con usos ad hoc, a voluntad y circunstancias del usuario. Así conviven el incremento del streaming (vía OTT $^{7}$ ) incluso para el vivo, el vídeo a la demanda para el diferido, otro tipo de visionados en streaming en smartphone o tableta y las prácticas multitareas (IAB, 2012).

13. El espacio mediático está muy relacionado con la democracia. Los media teóricamente conectan las opiniones sociales con las instituciones y se configuran como un espacio de pluralidad, de encuentro y de deliberación de los distintos agentes. Es un espacio de conocimiento, de agenda, propositivo, de reparto de juego, de control y de alimento de los procesos electorales y movilizadores.

4 Pone en circulación hechos, ideas, estéticas y valores y distribuye conocimientos; adapta la sociedad entera a los incesantes cambios sociales y económicos; recrea y transmite la cultura normalizada y prescribe valores dominantes; refuerza o debilita lenguas; establece los temas a discusión; crea sentidos culturales, sociales y políticos compartidos; y facilita la gestión del acontecer y de la acción pública.

5 Centro de Investigaciones Sociológicas (CIS): Estudio n ${ }^{\circ} 2836$, Barómetro de mayo 2010 (Población de 18 años y más).

6 «Since 2005, the key trends in the Spanish media market could be summed up as follows: the technological deployment of DTT production, broadcasting, and reception; the lack of economic rationality in DTT licensing due to close linkages between the political and the television market powers; limited gains in broadcasting quality following DTT switch-over, according to public perception; the growth of the Internet as an important news media platform; the increasing ideological polarization in both new DTT channels and online news outlets; the use of social media as political mobilization tools; the deep impact of the economic crisis, in terms of loss of funding, employment, and content quality and diversity; the resurgence of a state intervention model for the management of RTVE; an incipient conceptual change towards commercialism in the regional public service broadcasters, including privatization in some cases». Open Society Foundations "Mapping Digital Media: Spain”. 2012.

7 Video, audio o TV The Top (OTT) no requiere afiliación a los proveedores de servicios de Internet. 
El sistema mediático tiene como función ayudar a conformar nuestra imagen del mundo mediante una información veraz y plural.

Pero es un espacio distorsionado y desigual. Los media privados tienen responsabilidades públicas, más o menos exigibles, pero no son un espacio democrático sino, en su mayoría, una propiedad privada que busca acrecentarse. Hay contradicción entre la pluralidad ciudadana y el poder en el sistema de medios de comunicación. La oligopolización de las empresas de medios y la mercantilización de su oferta distorsionan el sentido de esas funciones, y convierten en un esfuerzo titánico la labor de tantos periodistas, empeñados en garantizar una información de calidad y en no subordinar la deontología profesional a las leyes del mercado.

Aunque hay bastantes medios de comunicación en el caso español, el resultado es que pocos Grupos multimedia controlan buena parte de ellos, y hacen que el pluralismo comunicativo deje mucho que desear.

En el caso español destacan cinco actores (Mediaset, Prisa, Vocento, RCS- Rizzoli-Unedisa y Planeta) que concentran más de la mitad del negocio mediático. Los 10 primeros (añadiendo Godó, Prensa Ibérica, Zeta, RBA y Ono) captaban hasta el $84 \%$ de entre las 32 primeras. Se trata de empresas cada vez menos familiares, pero algunas relevantes lo siguen siendo (Godó, Lara, Asensio, Gómez Junco o Moll) a pesar de estar cada vez más sujetas a la financiarización.

En efecto, hay una creciente y estrecha relación entre el poder financiero/económico y el mediático. Con la creciente financiarización, el nuevo tipo de gestores que toman las decisiones estratégicas en los media -y que son los agentes de confianza de los inversores institucionales- están alejados de las deontologías tradicionales mediáticas.

Solo Prisa y Mediaset facturaban más de 1.000 millones. Los operadores de telecomunicaciones también están presentes, pero esa es una parte minoritaria de su negocio. El sistema audiovisual privado conoce una concentración máxima en forma de duopolio conformado por Mediaset (Berlusconi) y el grupo Planeta (familia Lara) ${ }^{8}$. A mucha distancia y con serios problemas, Veo TV de Unidad Editorial (con cuatro canales y en parte alquilados) y Net TV (Vocento) con Intereconomía y tres canales alquilados (Disney, Paramount y MTV).

La Ley General de Comunicación Audiovisual (LGCAV) de 2010 propició esa concentración empresarial, redujo el servicio público de la radio y televisión a los medios de titularidad pública y liberalizó aún más la presencia publicitaria en la televisión.

La concentración de la propiedad en los medios es un problema. Los Grupos concentran poder ante el propio Estado, ante los periodistas que elaboran la información, ante los creadores que idean programas y, especialmente, ante la

8 Las fusiones de cadenas han configurado un duopolio privado dominante con Tele 5 (+ Cuatro) con siete canales en abierto y participación con Telefónica en el Canal+ del Grupo Prisa, y Antena3 (+Sexta) con otros siete y un canal de pago (Gol). Entre ambos acaparan $55 \%$ de audiencia y casi el $90 \%$ de la tarta publicitaria televisiva con un servicio público en retirada por imperativo legal. 
sociedad plural de la que no son reflejo. Son una élite propietaria con sus intereses particulares pasados como intereses generales y con su ideología. Buscan gestionar la opinión pública y el derecho de acceso de la población a comunicar. El tamaño de las empresas conforma posiciones dominantes en el mercado y permite influir decisivamente en la información, en los contenidos de la cultura de los países, así como en los mecanismos de precios y calidades.

El pluralismo mediático puede, a su vez, ser externo o interno.

El pluralismo externo se mide por el número de agentes reales, por su transparencia, por el nivel de competencia y el número de voces reales distintas (puesto que muchas empresas son de un solo propietario, de una sola voz).

En esta temática las tendencias llevan a que, junto a los procesos de concentración nacional, también se produzca una concentración transnacional. La titularidad de los grupos pertenece a grandes capitales, de orígenes nacionales distintos, aunque sigue habiendo dominio americano en el mundo: Time Warner, Universal, Disney, News Corp... El capital dominante que lo lidera aun procede del campo de los contenidos pero, crecientemente, entran empresas de telecomunicaciones, de la nueva economía o de la banca. Todas ellas quieren gestionar los contenidos. Habrá serios problemas si, como ya está ocurriendo, algunas empresas toman el control simultáneo de las redes y servicios del sistema de telecomunicaciones y las áreas de contenidos y plataformas, donde ya han tomado posiciones Google, Amazone, Facebook, Apple o Microsoft.

El pluralismo interno tiene varias vertientes. Una, profesional (relativa a periodistas, columnistas, opiniones) y que se expresa en el tipo de Libro de Estilo, en el nivel de cumplimiento de obligaciones de servicio público (para los operadores públicos) o de «interés general» (según la LGCAV para los operadores privados), en las pautas de autorregulación conforme a un código deontológico, con o sin Consejo y Estatuto de informativos. Otra vertiente del pluralismo interno es la social: los accesos de los sectores sociales significativos y menos significativos a la posibilidad de comunicación directa. Solo algunos RTVs públicas lo atienden.

Todo ello afecta a la calidad de la democracia.

Aznar apostó por conceder canales a Vocento y a El Mundo. La respuesta de Zapatero fue otorgarle canales a Sexta y Cuatro para compensar pero, al tiempo, asignó un múltiplex completo a cada uno de los seis operadores privados. La buena Ley de RTVE de la primera legislatura (2006) se vio ensombrecida por el Mr. Hide-Zapatero de la segunda legislatura, con la precarización de la financiación a RTVE, mientras autorizaba la concentración de los grandes operadores.

Todo ello puso contra las cuerdas a las TV autonómicas y locales, a las que Rajoy ha rematado con la apuesta por su privatización, cierre o externalizacion de servicios. Asimismo, con el Real Decreto Ley 15/2012, está sacando a TVE del espacio mediático de masas y ha traído de nuevo la gubernamentalización de RTVE. 
14. Esa estructura de la propiedad tiene consecuencias. Se vuelca en una TV de masas banalizada y sin más fin que las audiencias. En el caso español, los datos de audiencias de TV de octubre elevaban ya la audiencia media a 4horas 11 minutos diarios. Quiere decir que algunas franjas sociales están pegadas al televisor, puesto que hay otro sector que casi ya no pasa por él porque está en Internet (a veces también viendo TV).

Los nuevos liderazgos de T5 con 14,9\% de audiencia y A3 con 13,1\% en 2012, desplazan a TVE 1 al tercer lugar en menos de un año, con un 11,1\% de audiencia, en caída libre y al compás de su desmantelamiento. Ganan en peso la suma de los canales temáticos - propiedad de los mismos grupos- y bajan los canales autonómicos y locales, igualmente amenazados.

Esa concentración y esos liderazgos traen un doble daño:

Por un lado, una banalización de las programaciones (deportes, programas rosa, realities..) en claves de puro entretenimiento y estrechando su función de generación de opinión publica. En época de crisis se trata de que haya más fiesta que distraiga de la cruda realidad.

Por otro lado, y en el resto que queda, se apuesta por la espectacularización del debate político en tertulias convertidas en entretenimiento o en infoshows de sal gruesa y amplia demagogia. La TV ha protocolizado los formatos de espectáculo con programas de infoshow que se justifican como de participación social, en general, pero que retratan de forma caricaturesca una sociedad ignorante y manipulada. A ellos les acompañan un exceso de tertulias ruidosas y desequilibradas en su composición.

Se produce así una despolitización de la función mediática, unida a una repolitización doctrinaria y analfabeta en los márgenes por los que se pasean élites políticas u opinadoras omnipresentes, mientras se excluye a los actores sociales.

15. Hallin y Mancini (2004) clasificaron los sistemas de medios en países democráticos según los siguientes criterios: desarrollo de la prensa de masas, paralelismo entre agentes políticos y mediáticos, profesionalidad periodística e intervención del Estado. Todos ellos ámbitos donde las ideologías tradicionales tienen visiones distintas.

Detectaron tres modelos. El modelo democrático (Alemania) y el modelo liberal (anglosajón y más comercial) son eficientes en una hipotética función de vigilancia y de contrapeso mediático para la calidad del sistema democrático y para la madurez de la opinión pública. El modelo mediterráneo (España, Italia, Grecia) que es de «pluralismo polarizado», de partenariado político-mediático, o sea de compadreo de partidos y medios, de do ut des entre sistema de partidos y sistema comunicativo, significa una singular preeminencia de los intereses políticos sobre la comunicación en sí. Indica que los medios reflejan directamente a sectores y a intereses políticos y económicos. Y ello también ocurre en las comunidades autónomas del Estado Español. A ello hay que añadir el índice 
bajo de difusión de la prensa de información general $8,4 \%$ y de lectura del $38 \%$ (AEDE, 2012)

Se suponía que el espacio mediático es el espacio ciudadano de control sobre el Estado. Pero en el modelo mediterráneo resulta lo contrario. Es la correa de las instituciones políticas para señalar cómo pensar a la ciudadanía, y no solo sobre qué pensar, desde los espacios informativos, especialmente. Los gabinetes de información institucionales hacen la tarea de encaje. Así que desde las Facultades de Comunicación de la Universidad asumimos la contradictoria tarea de preparar a los futuros periodistas y comunicadores y, también, a quienes han de influirles relajando su celo.

Los media tradicionales dan la espalda a las tareas de vigilancia del poder, a la extensión del debate, a la visualización de los conflictos y a la diversidad social. No entra en sus parámetros el derecho de acceso de los grupos sociales a comunicar desde los media. Sustituyen esa función por la de cumplir con lo que se espera de ellas -con información intencional y dependiente- en función del espectro ideológico en el que se mueven. Habitualmente, se confunden hechos, opinión y propaganda.

Se han apartado del ávido lector de nuevo tipo que también navega y coteja lo que lee en los distintos media y exige más independencia informativa. Lo que está en crisis es el modo de edición de periódicos para un lector que no es enemigo del papel, sino del periodismo de consumo.

16. En el caso español el periodismo vive malos momentos y el periodista aun peores. El buen periodismo ha sido desplazado de la información. Pero la información interesa, y mucho. ${ }^{9}$

La difusión ${ }^{10}$ de la prensa ha caído un $20 \%$ en los últimos 5 años y la publicidad un 50\%. Han cerrado 67 medios, entre ellos varios de prensa diaria como Público o algunos gratuitos, mientras se experimenta con la prensa digital y nuevas formas de viabilidad económica. La independencia profesional de los periodistas, se ve amenazada por la precariedad e inseguridad laboral. En los últimos años han desaparecido 8.000 puestos de trabajo, de ellos más de 3.000 en 2012. ${ }^{11}$

Analistas, como Juan Varela, indican que no son situaciones inherentes a la digitalización sino, en buena medida, a los errores estratégicos de algunos medios de comunicación, ${ }^{12}$ incluidos los negocios de aventura extrainformativa que han arrastrado cuesta abajo la cuenta de resultados de los medios más exitosos.

9 «News, the preferred focus of this report, is being pushed into the state-owned, public service broadcast sector, and bulletins are privileged over more elaborate news genres, such as debates, documentaries and in-depth interviews». Open Society Foundations (2012: 119).

10 El País 10-11-12.

11 Unedisa-El Mundo y sus empresas han aplicado un ERE que afecta a 143 trabajadores; a sumar a los 150 despedidos anteriores. El País despidió en noviembre del 2012 a 129 trabajadores. Su deuda financiera neta está por encima de los 3.100 millones y sus pérdidas netas son de 451 millones de euros tras llevar a cabo importantes provisiones. Han salido más de 2.000 profesionales de la casa y se preparan más ajustes (El confidencial, 6-1-12).

12 «La crisis de El País no es solo un problema de negocio, de audiencia o de la irrupción de los nuevos medios y un nuevo mercado. Es una profunda crisis periodística y moral. Una terrible brecha de confianza entre empresa, dirección, 
La pregunta de las empresas de prensa debería ser: ¿Qué valor añadido debería darle al medio escrito si el mismo contenido es accesible de modo gratuito por la Red?

Que el periodista de a pie esté precarizado, cuando no despedido de su trabajo, y que se vea multifuncionalizado trabajando para la edición escrita y la Red, mientras no puede atender como se debe a las noticias, tiene sus efectos sobre la calidad de la información. Que vea vulnerados sus derechos profesionales en unos medios inadaptados a los cambios, se traduce en el desplazamiento de la buena información por el exceso de opinión, con cargo a editoriales cada vez más excesivos o a titulares de noticias sacados de contexto. También le desplaza la abundancia de columnistas, blogs o tuits de coste escaso.

No nos extrañará el reciente manifiesto en defensa de un periodismo al servicio de la ciudadanía del Foro de Organizaciones de Periodistas (Madrid, 26 octubre 2012) que dice así: «Los despidos, el empeoramiento de las condiciones laborales, las ofertas de trabajo esclavistas y los cierres de medios en los últimos años están causando un grave deterioro de la calidad informativa, limitan la independencia de los periodistas, debilitan el compromiso de la prensa con las libertades, el respeto a la intimidad y el honor de las personas, el pluralismo y atentan contra el derecho a un trabajo digno que garantiza la Constitución», ${ }^{13}$

Tienen razón. La libertad de expresión mediática es una prolongación derivada de la libertad colectiva. Implica una responsabilidad ante la sociedad y unos deberes para el buen funcionamiento de la democracia (Ramonet, 2004: 12).

En los años brillantes se creó una dualidad laboral en la mayoría de empresas. Por un lado, se pagaban grandes sueldos a periodistas y presentadores estrella y, por el otro, se instalaba la precariedad para la mayoría. De esto sí es corresponsable la propia profesión.

La profesión no debería ver como intruso al informador amateur que no busca lucrarse. El internauta de a pie no es enemigo del periodista profesional sino que colabora en la libertad y extensión de la información. Se requiere una alianza.

17. La importante labor compensatoria de los servicios públicos como RTVE (cinco canales) y las RTV autonómicas vive momentos críticos. ${ }^{14}$ Están en retirada por gubernamentalización o por acoso o por eliminación (algunos canales autonómicos).

El servicio público idealmente es el exponente del vínculo social en una comunidad y su referencia. Asume el punto de vista del país, fija valores en la opinión

redacción y público. La más dañina para la cabecera, para su audiencia y para el periodismo». Juan Varela, en Periodistas 21 (9-11-2012).

13 http://www.scribd.com/doc/111207607/Manifiesto-Foro-de-Organizaciones-de-Periodistas\#page=1

14 «The future of public service media as a state prerogative might be starting to disappear in Spain, at least at the regional level. The unfolding of reforms of regional public service broadcasters might result in complete privatization. In that case, the advantages of digitization would mainly benefit commercial actors». Open Society Foundations (2012: 122). 
pública, prioriza la producción del imaginario y reparte juego en la pugna de intereses. Nunca se destacará bastante la importancia del servicio público como tractor del conjunto del sistema mediático propio.

Ha de gestionarse no solo bien sino muy bien para evitar situaciones como las que se están viviendo. Los avances en el servicio público de RTV y en comunicación local y comunitaria logrados en los 80 , ya fueron desplazados tanto por la privatización centralizadora del sistema de radio (años 80 ), como por la oleada de TV privadas de ámbito estatal (años 90). El modo de implantación de la TDT ha multiplicado el peso de las emisiones privadas de ámbito estatal y con ello el sesgo centralista.

Por su parte, las radios comunitarias siguen en stand by, malfuncionando sin licencia, porque no se ha cumplido el compromiso de la LGCAV de asignarles una parte del espectro en un plan técnico ad hoc.

Como segunda conclusión. Paradójicamente en la era de la información todo conspira contra uno de los pilares de la democracia: la comunicación y el periodismo para generar una opinión pública de calidad.

\section{Comunicación analógica versus comunicación digital}

18. ¿Y qué aporta el mundo digital en ese panorama de problemas de la comunicación y de la cultura?

La era digital nos ha traído muchos más recursos de conocimiento sobre las realidades sociales que la era analógica (era de los medios de comunicación de masas y de las industrias culturales con ventas masivas de libros, discos o audiovisual) y en la que unas élites relativamente reducidas y especializadas, gestionaban el saber y la opinión pública. No hay por qué echarla de menos en muchos aspectos.

Cabe resumir algunos aspectos sustanciales en un cuadro. La primera columna señala los rasgos de la cultura y la comunicación en la era analógica; la segunda columna los del inicio de la era digital; y, la última, las tendencias con los consiguientes interrogantes que acompañan, por el momento, la implantación digital. ${ }^{15}$ Este cuadro nos está diciendo que hay lógicas nuevas de las que todavía sabemos poco. Se comentan sucintamente y en su orden.

15 Cabría presentar un cuadro mucho más amplio y complejo pero, a efectos expositivos, se han seleccionado éstos. 


\begin{tabular}{|c|c|c|}
\hline CULTURA ANALÓGICA & CULTURA DIGITAL & TENDENCIAS \\
\hline $\begin{array}{l}\text { Los medios de comunicación } \\
\text { gestionan la agenda y la Opinión } \\
\text { Pública (19) }\end{array}$ & $\begin{array}{l}\text { Se añaden agendas múltiples } \\
\text { que reestructuran el sistema } \\
\text { de información y en ocasión de } \\
\text { conflictos pueden imponer su } \\
\text { agenda }\end{array}$ & $\begin{array}{l}\text { Omnipresencia de las redes, } \\
\text { trend topics efímeros pero } \\
\text { empoderamientos desde algunos } \\
\text { ámbitos } \\
\text { ¿Límites? }\end{array}$ \\
\hline $\begin{array}{l}\text { Industrias separadas de } \\
\text { materiales, programaciones y } \\
\text { contenidos. Importancia del } \\
\text { soporte }(20)\end{array}$ & $\begin{array}{l}\text { Convergencia, multimediali- } \\
\text { dad con interactividad desde } \\
\text { Internet }\end{array}$ & $\begin{array}{l}\text { Doble naturaleza de la propia } \\
\text { Red: comercial y, en paralelo, } \\
\text { social media y entornos cola- } \\
\text { borativos } \\
\text { ¿Relaciones? }\end{array}$ \\
\hline $\begin{array}{l}\text { Media convencionales, y son } \\
\text { motores los editores /programa- } \\
\text { dores/ y Propiedad Intelectual } \\
(21)\end{array}$ & $\begin{array}{l}\text { Señores de las redes globales: } \\
\text { proveedores de servicios (Ama- } \\
\text { zon, Apple), plataformas (Fa- } \\
\text { cebook, Youtube), buscadores } \\
\text { (Google), aparataje (Microsoft, } \\
\text { Samsung). }\end{array}$ & $\begin{array}{l}\text { Nuevos distribuidores se apro- } \\
\text { pian y gestionan los contenidos. } \\
\text { Hay vulnerabilidad como socie- } \\
\text { dades vigiladas. } \\
\text { ¿Fiabilidad/responsabilidad de } \\
\text { los contenidos? }\end{array}$ \\
\hline $\begin{array}{l}\text { Jerarquía entre creador y usu- } \\
\text { ario y reglas del gusto. Cultura } \\
\text { pasada por la crítica. Expresi- } \\
\text { vidades y formatos específicos } \\
(22)\end{array}$ & $\begin{array}{l}\text { Cultura líquida, asociativa. } \\
\text { Flexibilidad y abundancia de la } \\
\text { producción amateur y consumos } \\
\text { productivos. Todos comunican. } \\
\text { Mix expresivos }\end{array}$ & $\begin{array}{l}\text { La Ilustración y la modernidad } \\
\text { redefinidas. Hipercomunicacio- } \\
\text { nes multi-bidireccionales. } \\
\text { ¿Transmedia y transformatos? } \\
\text { ¿Neomodernidad? }\end{array}$ \\
\hline $\begin{array}{l}\text { Brecha cultural y comunicativa } \\
\text { (23) }\end{array}$ & $\begin{array}{l}\text { Democratización digital pero } \\
\text { brecha añadida: interconectado- } \\
\text { res, conectados y desconectados }\end{array}$ & $\begin{array}{l}\text { Oportunidad de accesos } \\
\text { ¿nueva estratificación social? }\end{array}$ \\
\hline $\begin{array}{l}\text { Comunidades convivenciales. } \\
\text { Geografía con compartimen- } \\
\text { tación entre local, nacional e } \\
\text { internacional (24) }\end{array}$ & $\begin{array}{l}\text { Se solapan comunidades virtu- } \\
\text { ales. Globalidad con geografías }\end{array}$ & $\begin{array}{l}\text { Identidades básicas y subidenti- } \\
\text { dades múltiples. } \\
\text { Globalidad, cercanía y vínculo } \\
\text { son compatibles } \\
\text { ¿Diversidad vs. valores } \\
\text { compartidos cosmopolitas? }\end{array}$ \\
\hline $\begin{array}{l}\text { Hogar-castillo- espacio domésti- } \\
\text { co privado (25) }\end{array}$ & $\begin{array}{l}\text { Ciberhogar interconectado, } \\
\text { interferido y emisor }\end{array}$ & $\begin{array}{l}\text { Espacio público no político } \\
\text { pero emergen actores políticos } \\
\text { tecnológicamente dotados } \\
\text { ¿Interés creciente en la res } \\
\text { publica? }\end{array}$ \\
\hline $\begin{array}{l}\text { Economías de escala con mode- } \\
\text { los de negocio estables (26) }\end{array}$ & Crisis de los modelos & $\begin{array}{l}\text { Economías de Red, club, aten- } \\
\text { ción y experiencia } \\
\text { ¿viabilidad del sistema de } \\
\text { información y conocimiento? }\end{array}$ \\
\hline $\begin{array}{l}\text { Procomún histórico y apropia- } \\
\text { ción (27) }\end{array}$ & $\begin{array}{l}\text { Inmenso procomún amenazado } \\
\text { y rentabilidades también }\end{array}$ & $\begin{array}{l}\text { Mentalidades analógicas restrin- } \\
\text { giendo oportunidades digitales } \\
\text { ¿revisar la Propiedad Intelectual } \\
\text { por un estatuto del informador } \\
\text { y creador? }\end{array}$ \\
\hline
\end{tabular}

Fuente: elaboración propia. 
19. ¿Se ha horizontalizado el poder y la Tierra se ha vuelto «plana» como dice el gurú Thomas Friedman (2006) proclamando que se ha instalado una democracia electrónica y reticular, una gobernanza mundial difusa, ejercida desde la fluidez de la información entre millones de hogares y desde el acceso a toda clase de novedades creativas? ¿O estamos en una cosmocracia (Ortega, 2007) con valores y reglas compartidas y que dan lugar a poderes repartidos entre las potencias?

No lo creo. En ambas opiniones se soslaya el problema de los poderes reales. Ciertamente, hay un salto cualitativo en los saberes colectivos que vienen con la cultura digital, la multiplicación de accesos y la democratización de la parte visible de la información. Ese amplio espectro internauta (63\% en el caso español), desde su dominio de las herramientas comunicativas fuera del trabajo -quien lo tenga-, conversa todo el tiempo y sabe cada vez más. Una mayoría simplemente se comunica e informa -el $88,8 \%$ de internautas lee noticias en Internet según AIMC (2012: 87) - evitando con ello anomias sociales.

Los 2.400 millones de internautas, más de un tercio de la población mundial, tiene destrezas comunicativas y ha multiplicado el capital cultural y comunicativo humano, colectivo e individual, hasta límites inimaginables. La emergencia de media digitales, amplía cualitativamente las cuestiones de tratamiento informativo territorial o temático, atiende y da voz a colectivos antes ausentes. Gana, y mucho, el pluralismo.

Se desmiente así lo que hace diez años era una opinión que muchos compartíamos («es difícil vislumbrar en la Red espacios públicos como lugares de acción histórica del sujeto colectivo») ${ }^{16}$ para encontrarnos, hoy, con un espacio virtual -un no lugar pero muy real- de representaciones colectivas en diálogo y que se cruza con el espacio político.

Una parte de ella es una población tan culta como maltratada en el mercado de trabajo. Las mismas personas fuera de la Red, ven desvalorizarse su lugar en el sistema productivo, precarizarse sus derechos laborales y sociales, reducirse su nivel de vida e instalarse en la incertidumbre. Tal parece que se está dando una desposesión (Harvey, 2004) colectiva en la era de la comunicación y de los accesos a cantidades ingentes de información y de relaciones. Es un indicio fuerte de que cambio técnico y progreso social no son lo mismo, o de que lo uno no trae necesariamente lo otro.

En respuesta, ese usuario se escapa del mercado de los contenidos para obtenerlos de la Red -pagando el peaje publicitario- y genera una nueva y temible interactividad con sus impactantes y, muchas veces, efímeros trending topics. Es una extensión democrática y, para un sector, un eficaz activismo en tiempo real.

Los mismos que aportan su saber al sistema productivo y generan el excedente apropiado por el capital, usan el conocimiento en tanto usuarios para sus

16 Mireya Lozada: «Política en red y democracia virtual: la cuestión de lo público», en http://www.globalcult.org.ve/ pub/Clacso2/lozada.pdf 
propias finalidades, cooperan y ponen en cuestión los modelos de negocio de gestión de la cultura, la comunicación y el conocimiento. Introducen un factor de incoherencia en el sistema para su reproducción.

Ciertamente la intercomunicación y el acceso a múltiples contenidos, tienen una cierta función balsámica y de válvula de escape. Además, Internet como tal es un gigantesco negocio para operadores, buscadores, informática, suministradores, aplicaciones... Con todo, la socialidad en conexión cotidiana (AIMC, 2012: 35 ) es un hecho y una herramienta de cambio.

Una parte de ese espectro vigila a los poderes políticos democráticos y se empodera relativamente influyendo en la opinión pública y en las decisiones políticas, pero muchísimo menos en las económicas. Ese sector -nada homogéneo- es cada vez más influyente sobre el poder político, se centra en mejorar y democratizar el Estado e incide participativamente en la sociedad civil. Con todo, el otro poder, el económico, y ya no digamos el poder económico global, se le escapa de las manos, porque ya ha creado una gran zona opaca sobre la información más importante y estratégica.

Aun constatando una bastante mayor influencia social que en el pasado (Valencia, 1995: 450) la pregunta inquietante ya no es quién tiene conocimientos o información en la era del conocimiento (creadores, científicos, ingenieros, intelectuales, usuarios) sino quién tiene capacidad de adquirirlos y ponerlos a su servicio como recursos para su aplicación productiva, comercial, organizacional o política.

20. Hay una brutal pugna, no resuelta, entre la comunicación mercado y la comunicación intrasocial para hacerse con los usos de la ciberesfera. Posiblemente, se configuren dos espacios distintos pero muy relacionados.

Por el momento no tiene despejado el panorama el espacio comercial cultural y audiovisual por falta de reglas -la propuesta de ACTA también ha caído en el Parlamento Europeo, las normas de la Propiedad Intelectual son socialmente desacreditadas y transgredidas- pero sí ha logrado que sea gravoso para el usuario tener acceso a comunicar (equipos, telefonía fija y móvil, ordenador, tarifas planas) y que Internet sea un gran espacio de comercio electrónico (89\% dice comprar online), información, publicidad... Se van abriendo paso las plataformas de pago con cierto éxito, más en EE.UU. que en la UE.

La ciberesfera como tal, como red relacional tecnológica ya es comercial en sus códigos, formatos, protocolos y normativas legales. Y muy de pago. Y la libertad que ofrece es mediada, sobre todo, por liderazgos prescriptores derivados de los poderes «analógicos», aunque también por los emergentes en las redes. Hay una conducción denotativa de los significados preferentes por parte de esos prescriptores (media, periodistas, autores, poderes...). Incluso en el discurso de las redes sociales, esos agentes no están en el mismo nivel que los usuarios, con sus determinaciones o lugares sociales. 
Claro que ello no quita para que la novedad sea justamente la nueva socialidad como tal (y la pugna de hegemonías en su interior). Ante la tardanza de los sistemas convencionales de Poder en aparecer, emergieron esas múltiples voces que no podían acceder al sistema comunicativo analógico y que han visto multiplicada su influencia, especialmente sobre la generación joven.

21. El propio poder de los media analógicos se debilita en beneficio de muy pocas empresas globales tecnológicas y de redes. Éstos pasan a comandar la cadena de valor y a regatear el lugar de los creadores y productores de contenidos, que prefieren empezar a hablar con los proveedores de contenidos como plataformas y otros.

Esas empresas son inmunes, por el momento, a regulaciones o exigencias políticas de mínimos y pagan sus impuestos donde les parece. Se convierten en poderes sin controles. Y su buena imagen pública como innovadores ha de competir con su otra imagen, la de su impunidad, puesto que quedan fuera de mecanismos democráticos y de gobernanza.

Esas y otras empresas acumulan información sobre las sociedades vigiladas. Esa información fortalece a quien la gestiona. Las empresas privadas que disponen de listas de perfiles individuales y colectivos son poder y utilizan estrategias de relaciones públicas personalizadas, además de listas de usuarios con perfil que son objeto de comercio. Igualmente las administraciones acumulan información sobre las personas, para el momento en que piensen que deban utilizarlas. Si no hay regulación democrática con centro en el usuario, la vulnerabilidad será un sino colectivo.

Aquí se hace evidente la caracterización que hacía Edward O. Wilson (2012: 19) de las disparidades brutales en nuestra civilización: «Somos una civilización de Guerra de las Galaxias: emociones de la Edad de Piedra, instituciones medievales y tecnología que parece de dioses». Pues bien el desajuste regulatorio indica esa incapacidad para gestionar los aportes tecnológicos en beneficio colectivo, el procomún, mientras se ponen al servicio de algún poder «medieval».

¿Quién se hace cargo de la responsabilidad por los contenidos e informaciones cuando los unos dicen ser solo vehículo, y los otros no deciden sobre los contenidos que confeccionan o gestionan, porque no existe un régimen de autorizaciones y, en el mejor de los casos, sí de retornos económicos por los usos? Los señores de la Red «aunque no estén protegidos por la propiedad intelectual, lo están por los contratos que, de forma adhesiva, aceptan los usuarios y amparan la explotación de contenidos digitales» (Planas i Silva, 2011: 40).

Paralelamente a ese debilitamiento de los editores, el periodismo está en proceso de gran cambio: adaptación a la hipertextualidad, el multimedia, la ubicuidad del informador y del receptor o la redefinición de los sistemas redaccionales en dos direcciones: nuevas competencias e interactividad con los usuarios; y precariedad y multiplicación de tareas en el interior de las empresas de comunicación (blogs, miniblogs, conversación, formateados sucesivos). 
No es de extrañar; hay cambios copernicanos en los usos sociales.

22. La sobreinformación es desinformación cuando no pone los acontecimientos en relación con los procesos históricos o reales y los hace perder el sentido. El uso social de las tecnologías de la información introduce una potencialidad democrática que, para convertirla en hecho, exige volver a los fundamentos sociales de la información ${ }^{17}$.

La cultura digital amplía el sistema de comunicación de manera cualitativa, con nuevos ejes de espacio no geográfico y de tiempo no cronológico, pero no entierra la cultura y la comunicación propias de la era analógica, sino que las remodela. Esa explosión de comunicación incluso se produce en algunos medios convencionales como la TV, que sigue siendo el medio más exitoso, junto a los medios digitalizados y las comunicaciones por la Red. En cambio, la prensa escrita convencional y la radio, tienen dificultades económicas en la era de «todos comunicados».

Por una parte, como se trata de un espacio conversacional virtual -multi-bidireccional- y una nueva capacidad de conocimiento, que favorece el pensamiento en permanente flujo, poliédrico, mestizo, poco seguro, asociativo, global y «líquido», el problema pasa a ser la disposición de criterios para deambular con sentido entre tanto contenido. Ese flujo no nos hace iguales. Conocimientos, segmentaciones e idiomas marcan las preferencias conversacionales. Habrá que rescatar algunos principios y criterios clásicos de la modernidad como la libertad, la equidad y las igualdades de todo tipo, y complementarlos con otros emergentes, como la diversidad, la solidaridad, la fraternidad intercultural y el cuidado del planeta y de sus especies.

También se revaloriza el buen contenido y el buen periodismo. De la fascinación tecnológica por comunicar se está pasando -una vez adquiridas destrezas y dispositivos- a valorar contenidos que segmentarán a la población por gustos y conocimientos. Es más, los contenidos preferidos son obtenibles por el usuario desde distintas plataformas con preferencia por la pantalla (ordenador de mesa o portátil, móvil, tableta, TV) sobre la lectura, según tema, tiempo y lugar, y con capacidad de acción multitarea (ver TV tuiteando o una serie conversando). Eso le da opción, versatilidad y protagonismo al usuario. Se convierte en el centro de referencia del proceso -pasa del contenido al usuario polivalente y conectado en permanencia- pero no del mando. Para asegurar el flujo, son los distribuidores de contenidos y servicios, presentes en multipantalla, quienes tienen mando en plaza.

Por otra parte, que la Red sea a la vez un sistema vehicular de sistemas y un sistema específico, disuelve los formatos canónicos e invita a pantallas de usos distintos y al mix de formatos y formas expresivas.

17 «Del discurso racional, vertical y prescriptivo de la alta cultura se pasa a la que el usuario construye fragmentando y mezclando el orden abstracto alfanumérico de la lectoescritura con el orden más sensitivo de imágenes y con el conocimiento intuitivo, de prueba y error, dando lugar a nuevas significaciones. (..) Sin soportes y a coste casi cero, las herramientas de la creación y de la comunicación se extienden más fácilmente y permiten intercambios en todas direcciones, colectivizar los procesos productivos y romper la dicotomía entre cultura activa y pasiva» (Zallo, 2011a: 134). 
En especial, la TV está presente en todas las pantallas y con una estrategia de presencia multiplataforma, incluso con productos que buscan adaptarse a cada una de ellas. Consigue así que los medios digitales la complementen. Igualmente da lugar a que lo escrito profesional se desplace aunque, en cambio, el escrito amateur y conversacional gane muchos enteros en las redes.

Se intuye así que todos los media van a tener estrategias multiplataforma -todos en todo- pero las preferencias de los usuarios, en relación a las potencialidades de cada media y al propósito individual, les orientarán hacia usos diferenciados. Por ejemplo, la TV más para espectáculo, directos, información, magazines, series españolas, producciones bajo costo...; canales de pago para cine, series extranjeras, deportes; webs de TV en diferido y streaming para series; smart para directos, videos... Por el momento la plena integración espera a la TV conectada a la Red y que cuenta aún con pocos usuarios equipados y diestros (Varela, 2012).

En lo que a relatos transmedia se refiere -desde el cruce y especificidad de los distintos soportes, plataformas y media (Jenkins 2008)- tienen un futuro prometedor. Remodelarán los formatos y, quizás, cristalicen en transformatos o metaformatos. La idea tiene una oportunidad sobre la forma, después del barroquismo de las primeras etapas.

23. La brecha digital se añade a brechas anteriores. En febrero de 2005, la Organización de las Naciones Unidas lo interpretaba así: «La brecha digital que divide a los países no es insignificante: representa casi el doble del nivel medio de desigualdad de los ingresos». Bien es verdad que es inferior a la que supuso la brecha analógica, de la industria cultural, que ha necesitado un siglo en paliarse.

No todos los países, empresas o franjas sociales pueden ser interconectadores pero cualquier país debe intentar, primero, minimizar la bolsa de los desconectados en su ciudadanía y, segundo, sumar un máximo de interconectados y con incursiones productivas en segmentos como las aplicaciones o estimulando la proactividad en las redes. De no ser así el desajuste interno cultural puede ser tan grande que peligrarán incluso los avances en la democratización política y cultural y las agendas y cauces de opinión pública. Hay una batalla de muy diferentes signos en el interior de Internet.

No es solo cuestión de redes sino sobre todo de educación y de estímulos para aprovecharlas acotando, al tiempo, nuevas estratificaciones sociales.

24. Es evidente que no hay identidades únicas sino que todos somos un mix de identidades, pero unas son mucho más definitorias que otras.

No todas las culturas son iguales ante la Red. Las culturas centrales y de los grandes idiomas, los países con mejores focos tecnológicos e historial de oferta audiovisual o de videojuegos, multiplican sus oportunidades. Se amplía el desequilibrio ya no en el ámbito internacional (la idea de lo global no tapa las hegemonías en los flujos internacionales) sino que la proporción interna en cada 
país entre la producción propia y la procedente de algunos polos del exterior, se escora peligrosamente. A pesar de que se podrían potenciar mutuamente globalización, cercanía y vínculo, se reproducen hegemonías culturales que refuerzan unos espacios culturales e identidades a escala mundo.

Ello requiere un nuevo cosmopolitismo y una regulación a la altura de los cambios. Held $(2012: 75 ; 236)$ apunta ocho principios cosmopolitas para una gobernanza mundial alrededor de tres ejes: un universo moral (igualdad de valor y de dignidad; agencia activa; responsabilidad personal y rendición de cuentas); trascender desde las actividades privadas a marcos legítimos de acción colectiva (consenso, toma de decisiones colectivas en asuntos públicos; inclusividad y subsidiaridad); y orientaciones rectoras de acciones públicas (prevención de daños mayores y sostenibilidad).

Pues bien, estamos en mantillas tanto en bastantes de esos principios (incluso en las gobernanzas territoriales) como en hacer compatible ese cosmopolitismo con el reconocimiento de la diversidad que la subtiende y que se podría convertir en realidad si hubiera procesos de respetuosa integración, ajenos tanto a la pura asimilación como al melting pot multicultural.

Quizá haya una nueva oportunidad para que las grandes narraciones e ideales, los universales de la Ilustración y la Modernidad, y sus sujetos totalizadores y teleológicos (Hombre, Libertad...) se construyan con un viaje de ida y vuelta desde las realidades complejas y los reales y variados sujetos sociales hacia la ética, en una neomodernidad.

25. Los usuarios, antaño meros receptores silenciosos, han ganado con el ciberhogar y la movilidad mucho espacio y opciones. Incluso crean, producen y financian mutuamente (crowdfunding) pero, a falta de agendas colectivas, pueden instalarse en el ruido, en la comunicación mareante, en la charla sinfín mientras se escapa el sentido de las cosas, el real lugar social de la gente, los resortes para cambiar las cosas....

El hogar digital interconectado deviene espacio público transversal influyente aunque también con alta exposición a los agentes organizados. ¡Que se lo pregunten a los gestores de la campaña digital de Obama!

Pero en general, la gestión de lo colectivo se escapa entre los dedos en la era de las innumerables manos conectadas. Las redes sociales no son por sí mismas un espacio político. Espacio público y espacio político no son lo mismo. Este se genera desde la vertebración social y ciudadana como sujeto social y político, y desde las hegemonías de los poderes. Y ante ello las redes son una vía, no necesariamente la solución.

Claro que una minoría ampliada, tecnológicamente competente, pero de muy distintos signos ideológicos, está haciendo el tránsito desde la Red a la calle y desde la calle a la Red, generando un espacio público político vivo en el que, cuando menos, el debate se amplía cualitativamente. También es verdad que lo emocional y el juicio rápido, sumario y poco contrastado ganan demasiados enteros. 
26. Las sociedades complejas requieren muy buena información para gestionarse. Pasado este tsunami comunicativo con sus virtudes -la comunicación en el centro y compartida en conversación- y sus defectos -la comunicación en aluvión e invertebrada- seguramente se abrirá paso una etapa compartida de información de calidad y valorada socialmente con creaciones culturales exigentes, paralelamente a una continuidad de la información tous azimuts.

Las economías de escala (para reducir el coste por unidad o por usuario) persisten pero ceden lugar a las economías de red (su tamaño y viralidad) y de club (su perfil y connotación) que para construirse exigen previamente facilitar la disponibilidad (el acceso), captar el interés (economía de la atención) para una experiencia subjetiva, personal y expost (economía de la experiencia). El centro se desplaza hacia el usuario selector, su tiempo y su gestión. ¿Y el intercambio monetizable?

Los señores de las redes son los que salen beneficiados a costa de los dueños y gestores de los contenidos mientras éstos responsabilizan de sus desdichas a los usuarios ${ }^{18}$.

No es culpa del usuario. El negocio creativo, por el momento, no se monetiza pero el comunicativo sí. Móvil e Internet son un gran negocio. El gasto social en Comunicaciones (grupo 8) y Cultura (grupo 9) es del 9,4\% sobre el total del gasto personal en España, según la Encuesta de Presupuestos Familiares (INE, 2012). Pero siendo aún el doble el grupo de cultura, ha retrocedido $7,4 \%$ en 5 años mientras el grupo de "comunicaciones» ha crecido un $10 \%$ en el periodo 2006-2011. Se estancan el gasto por persona en equipamiento y servicios culturales y baja en prensa y edición un $17 \%$. Llama la atención que, en cambio, el grupo de «educación» suba un $17 \%$.

Pero eso no genera mercado suficiente para absorber la oferta comercial, lo que redunda en crisis de sectores culturales y comunicativos y del empleo y de las remuneraciones. «La sociedad actual es abundante en información y escasa tanto en tiempo como en atención» (Campos, 2010: 24). Captarlos obliga a revisar códigos y unas calidades que cotizan a la baja.

¿Es viable el sistema comercial, tal y como está pensado como mero traslado de lo analógico a lo digital? Creo que no. Ya explicó Eli Noam sus dudas sobre la viabilidad del sistema de gestión. ${ }^{19}$

El problema se complica cuando dada la inversión del usuario en aparataje y red no deja mucho espacio para que remunere, además, a contenidos de alto valor añadido

\footnotetext{
18 Por primera vez las siete principales entidades de gestión de derechos (Sgae, Vegap, Dama, Agedi, Aei, Aisge, Egeda) apoyadas por sus homónimos internacionales, en su «Manifiesto. 25 Aniversario de la Ley de Propiedad Intelectual» (diciembre 2012) ponen el foco no en el usuario, otrora criminalizado, sino en la industria tecnológica: «No queremos que los ciudadanos paguen la compensación por copia privada, vía Presupuestos Generales del Estado, sino la industria tecnológica que se beneficia de la misma, tal y como sucede en el resto de países de la UE».

19 «A market failure exists when market prices cannot reach a self-sustaining equilibrium. The market failure of the entire information sector is one of the fundamental trends of our time, with far-reaching long-term effects, and it is happening right in front of our eyes» (2004). Ver también Petit 2012:88.
} 
y precio. En la medida de que no hay mercado se realizarán producciones de menor coste y valor económico. Con lo que la motivación para que el usuario se incline hacia ellos se reduce. Se acercará a lo disponible que, en la Red, se convierte en lo masivo y de coste marginal descendente, propenso a la gratuidad.

27. Paralelamente, si los mercados del copyright no son viables pero, en cambio, hay un éxito de Internet ¿no debe motivar a impulsar el procomún ${ }^{20}$ y las comunicaciones libres como parte del capital humano pero también como una clave de participación democrática? Y, al mismo tiempo, ¿no se debería abundar en sistemas de abono general para acceder a contenidos de todo tipo, más selectivos o de alto valor añadido?

En el Estado español no se piensa en estos términos. Se ha constituido en 2012 el lobby del Observatorio de la Propiedad Intelectual para, al alimón con el Gobierno, repensar la legislación y estrategias centradas en la Propiedad Intelectual, en lugar de en la autoría y sus derechos, el usufructo o el procomún.

Mentalidades analógicas quieren restringir las oportunidades digitales y aunque usen como argumento la necesidad de los retornos al creador y el mantenimiento de la creación profesional, estos se defenderían mejor desde un estatuto del informador y del creador. ${ }^{21}$

Como tercera conclusión. Lo que tiene de oportunidad la era digital para la comunicación, la socialidad y la democratización, también lo tiene de amenaza profunda para las sociedades y culturas, como el campo de minas y de intereses muy estratégicos que es, en el marco del cada vez más desigual capitalismo global.

\section{De la democracia minimalista a la relacional}

28. En la era analógica se han sucedido muchos tipos de democracia pero, en general, han sido meramente representativas y de rutinas rotatorias electorales,

20 Son bien comunal o procomún en general lo que heredamos y creamos conjuntamente y que legaremos a las generaciones futuras. En la Red lo conformarían las prácticas de compartir y remezclar, las licencias alternativas, el software de código abierto, la deuda social del creador, la web colaborativa, los servidores de listas por grupos de afinidades, archivos compartidos entre iguales (peer to peer). Son nuevas formas de colaboración productivas.

21 La remuneración de la autoría podría tener tres partes:

«a) Una parte, mediante precio, es alcanzable en el mercado de soportes físicos, medios de comunicación o artes escénicas y musicales (edición de libros, de música, exhibición, espectáculos...) y en el intercambio por la Red, y mediante eventual subvención en los casos de operas primas o proyectos costosos.

b) Otra parte, los retornos de la creación que circula por la Red sin contraprestación directa, se podrían derivar de un Fondo sostenedor del procomún (no representaría solo a los artistas) con cargo a los presupuestos públicos del Estado (o administración integral) y que para dotarlo debería elevar algún punto la fiscalidad directa. El cuánto es cuestión de cálculo razonable. Lo lógico en esa segunda parte sería una sola exacción general válida para todos los supuestos (uso de copia privada, descargas, streaming, intercambios...) y sustitutiva del canon y de la hipotética remuneración por descargas sin intercambio monetario.

c) Una última parte -también para el Fondo anterior- se derivaría de una tasa sobre ingresos de las compañías usuarias de contenidos (..) operadoras de telecomunicaciones (..) buscadores, servidores y plataformas» (Zallo, 2011b: 297). 
de protocolos institucionales, de división de poderes y de atención a la opinión pública desde un concepto vertical y paternalista.

En la tradición minimalista de nuestras democracias representativas, los gobernantes no se ven responsables ante los ciudadanos, ni necesariamente atienden sus demandas. No es un problema de naturaleza personal o ética sino de lógica sistémica, a la que felizmente algunos políticos serios como servidores públicos contradicen, mientras la mayoría sólo busca cuidar su imagen para las urnas siguientes. Algunos políticos ni eso, porque las listas cerradas animan solo a la lealtad y al clientelismo interno en el partido. Los procesos y las prácticas de la democracia representativa han degenerado. Los representantes se representan a si mismos y a intereses de poderosas minorías. Están desconectados -y por ende incontrolados- de las voluntades ciudadanas. Hay así un importante desprestigio, con excepciones significativas, de políticos y de sus privilegios.

Si a ello le añadimos la tardanza, cuando no abandono, en la resolución de problemas, se produce una crisis de legitimación política que, con el tiempo, podría dar lugar a un movimiento de barrido de la élite política actual, como ya ocurriera en la Italia de la Tangentópoli.

La demanda, hoy, de democracia plantea una sustancial regeneración de modelos y rutinas de la democracia representativa.

29. En la actualidad coinciden en el tiempo dos tipos de tendencias fuertes. Por un lado, el desplazamiento de la política por las finanzas lo que conlleva una crisis democrática y una deriva autoritaria, incluso represiva. Por otro lado, la crisis de legitimidad democrática, que viene acompañada en la era digital de la explosión de información -y el consiguiente interés ciudadano por la misma- y con estructuras flexibles nuevas como las comunidades virtuales y las redes sociales.

Para afrontar la crisis democrática cabe fijar algunos objetivos tan deseables como exigibles.

En primer lugar, las democracias deberían medirse por su capacidad de canalizar y resolver aquellos problemas que se entienden como de interés general, aunque sea difícil definirlos colectivamente.

Habida cuenta que las normas y leyes son instrumentos para resolver problemas, lo sensato, en lugar de atrincherarse en ellas para fijar ventajas adquiridas, sería cambiarlas cuando crean más problemas de los que resuelven. Algo de esto ocurre con el debate sobre la estructura territorial y nacional del Estado.

Hoy -más allá de los déficits y deudas varias- esos problemas desatendidos son, al menos, la crisis y el inexistente proyecto de salida, el bienestar, la globalización, la interculturalidad, la ecología, la estructura organizacional territorial acorde con el pluralismo nacional en varios países... y la propia democracia. 
Es decir, no cabe cambio democrático y de sus reglas -so pena de quedarse en lo institucional y procedimental- si en su camino no se abordan simultáneamente los problemas sustantivos (globalización y gobernanza mundial, la deuda del cada país, repensar la UE, la recuperación...).

En segundo lugar, deberían cotejarse las democracias por sus pautas de respeto a la libertad, la justicia y los derechos humanos desde procesos electorales y participativos con todas las opciones propias del pluralismo.

En tercer lugar, deberían caracterizarse por contar con un sistema institucional organizado y funcional, tratando a los distintos grupos sociales con ecuanimidad y sin que haya colectivo alguno excluido. En este aspecto la brecha digital es un problema añadido.

No hay desinterés ciudadano, en absoluto, sino desistimiento y resignación de unos, y enfado creciente, de otros. Ambos sectores ven muy alejada y autónoma a la élite política que se autoreproduce al margen de los avatares colectivos. Con ello las legitimidades democráticas mismas son contestadas.

En cuarto lugar, frente a quienes piensan que hay una pérdida colectiva del sentido de lo público cabe decir -vistas las reacciones sociales en el drama de los desahucios- que la solidaridad es un valor en alza. Y ello en una época más propia para el sálvese quien pueda al que invita la clase gobernante porque se ha instalado en ella. Tienen horror a los procesos colectivos que, como un Guadiana, emergen en épocas de crisis.

En mi opinión se están poniendo las condiciones para una ciudadanía cívica que exige nuevas reglas para lo colectivo y no se deja atrapar por las respuestas protocolarias o evasivas y que quiere democracia, sí, pero de otro tipo.

En último lugar, es exigible que se tomen las decisiones políticas de forma radicalmente distinta. Ciertamente la democracia hace referencia al deber de tomar decisiones justas, pero más todavía a que sean los ciudadanos los que tomen esas decisiones de acuerdo con sus intereses, identidades, proyectos y esperanzas colectivas. De acuerdo con el Bien Común, el bien de las grandes mayorías. Solo si los ciudadanos deciden es posible obtener Justicia.

30. Es verdad que en los últimos 30 años se han producido cambios en positivo en Europa en relación a los sistemas democráticos: los organismos independientes reguladores (Rosanvallon, 2009:13) -como los Ombudsman y Consejos del audiovisual o de la Competencia- o los Tribunales Constitucionales más o menos garantistas, los bancos centrales más o menos autónomos, la obligada comunicación institucional y política o la e-Administración. Asimismo cabe decir que cultivar la imagen y el prestigio de los gobernantes les exige gestos de proximidad con la ciudadanía, apareciendo cerca de sus problemas, compartiendo valores, mostrando sentimientos y despertando emociones. 
Están también las iniciativas de Open Government (Gobierno abierto) que democratizan el acceso ciudadano a la administración electrónica, o el voto electrónico y la información al instante.

Pero es poco porque, vistas las querencias sociales, los planteamientos de la doctrina moderna se dirigen hacia la democracia deliberativa o relacional, más allá de sus hipotéticas herramientas (como podrían ser la ciberdemocracia o la democracia electrónica).

La democracia relacional atendería el espacio electoral de reproducción, la gobernanza con comunicación, las relaciones con los movimientos sociales y los procesos locales de participación (Ibarra, 2011: 37). Combinaría la democracia representativa con la participativa y con la directa (consultas, derecho de iniciativa..). El concepto habría cambiado; no solo mediante la transparencia, la responsiveness - la capacidad de respuesta a las demandas ciudadanas- y la accountability -la rendición de cuentas- sino que los ciudadanos tendrían derecho a participar, afirmándose como comunidad que se autogobierna.

Es un cambio de concepto. El autogobierno no es delegación sino una función asignada a los electos en interacción social para la decisión colectiva. Es decir los representantes estarían comprometidos con las demandas de los ciudadanos, y habrían de tomar decisiones delegadas de esa voluntad ciudadana.

Va, por lo tanto, más allá de la gobernanza. Esta es una ayuda para la legitimación de las políticas públicas y un modo de relación institucional, pero el sistema enmarca la acción de los actores sociales relevantes y asume por si mismo las decisiones sobre distintos recursos.

Esos ejes de redefinición (más que una regeneración) democrática serían: la transparencia; cambios de los procesos electorales; limpieza de corruptos hasta dignificar los cargos como servidores públicos; lograr que vayan los mejores, vocacionales e intachables; derecho de consulta como en Suiza o USA; listas electorales abiertas; institucionalización de la fiscalización de los representados sobre los electos; respeto a las comunidades; presencia de todos los grupos sociales en los procesos decisorios, etc.

En el ámbito de la estructura de Estado se revalorizan las ventajas de las unidades intermedias o más pequeñas para la democracia (Colomer, 2006: 117) porque cuentan con un conocimiento cercano para la deliberación, la compartición de intereses para la decisión y el compromiso para la ejecución. Claro que en el caso español ello se traduce en dos vertientes diametralmente opuestas: la reivindicación soberanista de unos y la reclamación de disolución del sistema autonómico de otros.

Hoy se demanda que la representación debe complementarse con procesos participativos democráticos. Con espacios reglados en los que la ciudadanía delibere y formule propuestas colectivas y que tales propuestas sean asumidas por los y las representantes institucionales. O sea una verdadera democracia 
representativa enriquecida por las democracias participativa y puntualmente directa. Ese es el reto.

31. Hablar de sistema político es también hablar del sujeto social y político que busca hegemonizarlo en sustitución de las actuales clases dominantes comandadas por el capital financiero.

Laclau y Mouffe (1987) -reinterpretando a Gramsci- criticaban la cuestión del sujeto único alternativo -la clase trabajadora como aglutinante de la lucha contra todas las opresiones y catalizador de todas las rebeldías- y proponían la idea de un sujeto democrático colectivo capaz de sumar, para una nueva hegemonía, todas las demandas sociales de una sociedad moderna y diversa contra las subordinaciones múltiples. Reivindicaban, desde su idea de la crisis de la modernidad y de los sujetos idealizados, la «revolución democrática» y la noción de «democracia radicalizada y plural».

Es discutible una radicalización democrática per se porque no se ve cual es su contenido y proyecto, ni sus sujetos y hegemonías ${ }^{22}$, pero esa tesis resalta la importancia del modelo político democrático en las sociedades abiertas. Asimismo pueden producirse amplias alianzas por la base a nivel mundial entre los nuevos movimientos. ${ }^{23}$

32. El interés por la información y la res publica crece al compás de la opulencia comunicativa y de un nuevo tipo de autoorganización en miríadas de redes que conforman una multitud inteligente.

Con Internet cabe así mayor participación, debate, deliberación, transparencia, respuesta a demandas y rendición de cuentas. Hay enormes posibilidades de chequear opiniones a diario y de realizar consultas electrónicas indicativas sobre temas de interés.

Paralelamente, la Red puede ser una fantástica herramienta movilizadora como se pudo comprobar, ya hace una década, con los movimientos alterglobalistas (Seatle, Cancún, Génova) o, más recientemente, con los movimientos de democratización (norte de África) y de expresión ciudadana ante la inoperancia del bipartidismo institucional español (15M, 25S y 14N).

33. Pero la información no contrastada de la Red, la propaganda, el manejo de emociones y la inmediatez también pueden hacer estragos en una democracia. Hay además una creciente presencia en el espacio público de Internet de mensajes comerciales o políticos, listados en oferta, spams, publicidad...

22 Daniel Bensaid (2009: 330 y ss) criticaba estas tesis en esa misma dirección.

23 «These might be the signals of the coming of stronger alliances between various types of actors. Who knows may be we can this time achieve to form a 'Fellowship of the Ring', using Tolkien's fictive image as a metaphor. A force that can attract the eye of the Mordor, murderous 1\% in our case, to herself and expand from the Middle Earth (Europe) towards the Mediterranean, Middle East, the Americas and across the world. Charge a glorious battle against the common enemy who declared economic, social, political, cultural and military class war at the $99 \%$ and the planet itself» dice Michel Bauwens (22-10-2012) 
No se pueden tomar decisiones por democracia electrónica inmediata. Los consensos y las hegemonías en los proyectos colectivos no es la suma ni el cruce de opiniones sino el resultado, desde procedimientos aceptados, del contraste político, del conflicto y de las legitimidades confirmadas en la representación.

34. Todo ello replantea algunas claves en las democracias.

a) Encauzar el interés en la res publica es sustancial para una democracia deliberativa centrada en decisiones responsables que atiendan al interés general.

La actual pérdida de sentido de la política, como contrato de convivencia en libertad y de bien colectivo, exige correspondencia entre percepciones ciudadanas y decisiones políticas; solo así se renovará ese contrato de ciudadanía. Igualmente para los modelos de gobierno multinivel o para los divorcios políticos amistosos.

b) La información y la comunicación son centrales para gestionar las percepciones.

Y ahí la Red y las redes pueden ser de una gran ayuda aunque no es automática y, también, puede servir a finalidades bien opuestas. En todo caso su inexistencia generaría inflexibilidad autoritaria y se traduciría en colapsos.

c) Ello supone, asimismo, volver a pensar la estructura de medios de comunicación, incluyendo la función de los servicios públicos, las obligaciones sociales de las entidades privadas y el lugar del periodismo en ella. Van a seguir siendo los focos de la información contrastada, ya sea analítica para las élites, o divulgativa para la comunicación masiva. La Red no nos ahorra este tema.

35. Ya hace 30 años la ciberdemocracia se planteó por algunos tecnoutopistas (Tofler, Masuda, Naisbitt...) como medio fundamental para afrontar la crisis democrática. Al Gore siguió esa estela. El concepto abarcaba distintas áreas de interés: la circulación de la información misma, las relaciones entre la Administración y la ciudadanía, sus efectos sobre las políticas públicas y sobre el sistema democrático como tal. Obviamente estaban pensadas esas aportaciones en claves de refuerzo sistémico y de absorción de hipotéticos conflictos.

Desde luego, hay que interrogarse sobre mecanismos que compatibilicen la democracia representativa, la presencial y la cibernética. Pero ello también interpela a definir el Estado red que conecte lo hiperlocal, que garantice la topología de red distribuida y capilar, que facilite la participación. Un Estado red que propicie el empoderamiento ciudadano y la cocreación de iniciativas. Un Estado red que debilite la influencia de las superestructuras financieras y políticas (Gutiérrez, 2012).

Ha habido excesivas fantasías sobre la teledemocracia. La ilusión de la teledemocracia -que criticaba Martín Cubas (2001: 50-51) - se basaba en una supuesta intervención ciudadana directa, casi igualitaria y heterárquica en los asuntos públicos, en tiempo real y sin intermediarios, palpando los gobernantes la opi- 
nión directa de unos ciudadanos con acceso a tan amplia información como la de ellos mismos. Se ampliaban así cualitativamente la libertad de expresión y el pluralismo; y se producía la intervención ciudadana directa en la formación de la opinión pública.

Pasada esa ilusión hay acercamientos más modestos sobre sus potencialidades.

De los distintos modelos teóricos (Prats y Álamo, 2003), hay una nueva idea de «teledemocracia» que da preferencia a formas de democracia directa y a la información política y se centra en el voto y la actividad política de participación. La idea de «ciberdemocracia» se centra en crear comunidades (virtuales y no virtuales) para contrarrestar las formas centralizadas de gobierno. La «democracia electrónica» incide más en reforzar la democracia representativa con más intercambio de información y participación.

Algunos ejemplos de vías tecno-políticas abiertas serían: los ciudadanos enviando propuestas políticas que agrupadas luego puedan ser votadas, o el voto de los presupuestos tras debates sociales (Gabinete Digital de Rio Grande do Sul ${ }^{24}$ ). En Islandia, el reciente proceso constituyente se apoyó en una plataforma wiki y en las redes sociales. El movimiento «Rodea el Congreso» en el Estado español ejerció el derecho de petición (Democracia 4.0) exigiendo el derecho de voto activo y directo (participación en la tarea legislativa, transparencia con una Sede Electrónica del Congreso de los Diputados...).

En cuanto a la participación, las posibilidades de acciones en Red se multiplican. Por ejemplo, las asambleas registradas en tiempo real o las conexiones transversales entre diferentes asambleas y grupos.

A modo de cuarta conclusión. Un mix de los tres modelos y vinculándolos a la democracia relacional significaría: ayudar a la existencia de una potente información on line y off line y de calidad; favorecer la autoorganización social en lugar de obstaculizarla; reforzar la legitimidad de la democracia representativa con su mejora cualitativa (listas abiertas, consultas, fiscalización de electos); multiplicar los espacios codecisionales como los Presupuestos desde la participación ciudadana, como en Porto Alegre.

\section{Algunas bases para una comunicación democrática}

36. Los temas suscitados no son abordables sino desde muchos frentes: luchas y resistencias sociales; nuevas narrativas que hilen ética y cambio sistémico; gobernanza global; políticas económicas pensadas para la sociedad; democratización de los sistemas políticos; densificación y cruce de las comunicaciones...

24 «Criado em maio de 2011, a concepção do projeto foi acompanhada de uma ampla pesquisa que analisou exemplos de democracia digital do Brasil e do exterior e inspirou a criação de um conjunto único de mecanismos para a participação. Os canais abertos pelo Gabinete Digital já propiciaram importantes resultados como a geração de políticas públicas e definição de ações pelo Governo do Rio Grande do Sul» (http://gabinetedigital.rs.gov.br/) 
Demasiados retos para que los resuelva la comunicación aunque son imposibles de afrontar sin ella.

Se trataría de pensar en los problemas a largo plazo desde la desazón de saber que el sistema no lo hará de motu proprio y que, en todo caso, lo hará porque se le fuerce desde quienes no están en los centros de decisión. Claro que hay un campo de actuaciones propias que no dependen del sistema político. Por eso parece útil diferenciar los temas justamente por ese criterio: lo que cabe exigir al sistema institucional para que lo haga y lo que podemos hacer autónomamente, por nosotros mismos.

37. En el plano de las reivindicaciones al sistema institucional.

- La centralidad de las políticas culturales y comunicativas buscando revertir las políticas de comunicación de los últimos años y poniendo el énfasis en el derecho de acceso a la comunicación, la calidad y el pluralismo informativo.

- Volver a poner en el centro del desmejorado sistema mediático a los servicios públicos de RTV, corregir el oligopolio comunicativo con el apoyo a los medios de comunicación de menor peso y a todo el sistema micro de prensa en Internet; así como dar amparo legal a las radios comunitarias mediante un Plan Técnico que les permita cumplir sus misiones sociales sin convertirles en radios de escalera.

- Acceso general a las tecnologías y campañas de formación y la introducción en los usos de Internet a las generaciones de más edad.

- La educación política ciudadana y de los valores de la información desde la escuela, la universidad y los medios.

- La apuesta por la producción propia y por contenidos que respondan a una información veraz e independiente, con criterios de cercanía territorial y difusión de valores culturales y de servicio social.

- Ayudas a los medios para el mantenimiento del empleo y a los proyectos innovadores que creen condiciones de futuro con cargo a la política industrial y de innovación de los gobiernos, y motivadas en políticas de impulso democrático.

- Reclamar la descongelación del proyecto de ley de Derecho a la Información de la Ciudadanía.

- Continuar la tramitación del Proyecto de ley de Transparencia, Acceso a la Información Pública y Buen Gobierno, aprobado en el Consejo de Ministros de 27 de julio de 2012, y susceptible de mejoras en el Parlamento

38. En el plano autónomo de los usuarios de Internet, los profesionales, los investigadores. 
- La defensa del empleo, las condiciones de trabajo, la negociación colectiva y la dignificación y valores de la profesión comunicativa, reivindicando libros de estilo, cartas de deontología profesional y estatutos de la redacción.

- La formulación social de los derechos fundamentales de los internautas podrían ser parte de una recogida de firmas para una Iniciativa Legislativa Popular ante el Congreso de los Diputados o los Parlamentos de las Comunidades Autónomas, tal y como se está haciendo en relación a los desahucios, y en dos planos:

- Derechos: a la conexión, a la privacidad, a obtener un nombre de dominio -especialmente relevante en las comunidades con cultura integral-, a la seguridad de las transacciones o a la homogeneidad de los protocolos.

- Gestión de la Red: neutralidad de la Red; tarifas justas; regulación de los oligopolios; universalidad de la banda ancha para toda la ciudadanía en claves de accesibilidad y asequibilidad; velocidades aceptables; servicios; derechos de autoría compatibles con el acceso a la cultura; la lucha contra la intromisión de vigilancias privadas en la Red fuera de las tutelas judiciales...

- Importancia de la descentralización comunicativa (incluida la creación de espacios comunitarios en la Red) y revitalización de las RTV comunitarias.

- Extensión de las redes sociales y su conexión con movimientos vivos capaces de acción social.

En suma, un largo camino para poner la comunicación, dondequiera que se produzca, al servicio de las personas, de la redefinición democrática y del cambio social.

\section{Bibliografía}

AIMC (2012). Navegantes en la red. $14^{a}$ encuesta AIMC a usuarios de Internet. Febrero 2012, disponible en: http://download.aimc.es/aimc/f5g9/macro2011. pdf. [29/10/2012].

Bauwens, M. (2012). «Essay of the Day: The dramatic rise of $p 2 p$ communications within the emancipatory movements». Disponible en: http://blog.p2pfoundation.net/essay-of-the-day-the-dramatic-rise-of-p2p-communications-within-the-emancipatory-movements/ [29/10/2012]

Beck, U. (2001). Qué es la globalización. Falacias del globalismo, respuestas a la globalización. Barcelona: Paidós Ibérica.

Bensaid, D. (2009). Elogio de la política profana. Barcelona: Ediciones Península. 
Burch, S. (2012). "Los paraísos fiscales y la fuga de capitales". Alainet 2012-10$30 \mathrm{http}: / /$ alainet.org/active/59232

Campos, F. (2010). «Gestión de la transición del cambio mediático». En: Campos, F. (Coord.). El cambio mediático. Zamora: Comunicación Social, Ediciones y publicaciones.

Colomer, J. M. (2006). Grandes imperios, pequeñas naciones. Barcelona: Anagrama

Fontana, J. (2011) "Por el bien del imperio. Una historia del mundo desde 1945”. Pasado y presente 2011

Foro de Organizaciones de Periodistas (2012). Manifiesto en defensa de un periodismo al servicio de la ciudadanía. Madrid, 26/11/2012.

Friedman, T. (2006). La tierra es plana. Madrid: Mr ediciones.

Gutiérrez, B. (2012). «Democracia en red». Zona Critica. Disponible en: www. eldiario.es (22-11-2012).

Harvey, D. (2004). «El nuevo imperialismo: acumulación por desposesión». Disponible en: http://biblioteca.clacso.edu.ar/ar/libros/social/harvey.pdf $(22 / 11 / 2012)$

Held, D. (2012). Cosmopolitismo. Ideales y realidades. Madrid: Alianza.

Henry, J. S. (2012). «The Price of Off-shore Revisited, Tax Justice Network». Julio 2012. Disponible en: http://tjn-usa.org/storage/documents/Price_of_Offshore_Revisited_72612.docx. (22/11/2012)

IAB Europe (2012). Mediascope Europe. Spain results (junio 2012).

Ibarra, P. (2011). Democracia relacional. Madrid: Centro de Estudios Políticos y Constitucionales.

Jenkins, H. (2008). Convergence Culture: la cultura de la convergencia de los medios de comunicación. Barcelona: Paidós Ibérica.

Keane, J. (2009). «Democracia monitorizada. La historia secreta de la democracia desde 1945». Conferencia en la UJI (05/02/2009).

Laclau E.; Mouffe Ch. (1987). Hegemonía y estrategia socialista. Hacia una radicalización de la democracia. Madrid: Siglo XXI de España editores.

Martín Cubas, J. (2001). Democracia e Internet. Valencia: UNED.

Mattelart, A. «Sociedad del conocimiento, sociedad de la información, sociedad de control». Entrevista realizada por Antonia García Castro disponible en: http://www.infoamerica.org/documentos_pdf/mattelart10.pdf (22/11/2012) 
Noam, E. (2004). «Market failure in the media sector». 16 de febrero de 2004. Disponible en: http://www.citi.columbia.edu/elinoam/FT/2-16-04/MarketFailure.htm $(23 / 11 / 2012)$

Open Society Foundations (2012). Mapping Digital Media: Spain.

Petit, M. (2012). Por un mercado inteligente. Diversidad cultural, mercado y regulación”. Barcelona: Erasmus.

Planas i Silva, C. (2011). «Los contratos editoriales en la era del acceso: la desintermediación legal». En: Torres Ripa, J.; Gómez J. A. (Coords). El copyright en cuestión. Bilbao: Universidad de Deusto.

PNUD (2004). Informe sobre Desarrollo Humano. Madrid: Ediciones MP.

Prats, J. O.; Álamo, O. del (2003). «Democracia electrónica: concepto, tipos y posicionamientos». Disponible en: http://www.rimisp.org/fida_old/documentos/ docs/pdf/0040-002035-democraciaelectroacutenica.pdf

Ramonet, I. (2004). «Prólogo: información y democracia en la era de la globalización». En: Agora. Revista de Ciencias Sociales, $n^{0}$ 10. Valencia: Fundación CEPS.

Rosanvallon, P. (2009). «La nueva legitimidad democrática». En: Pentsamendu Taldea Hausnarketak, núm. 23. Gasteiz: Gobierno Vasco.

Valencia, A (1995). «La teoría política en la era de la tecnocracia». En: Vallespin, F. (Ed). Historia de la Teoría Politica. Alianza Editorial.

Varela, J. (2012). «El futuro de la televisión: nuevo consumo, otro negocio», Conferencia en UPV-EHU (19-12-2012).

Vázquez, S. (2011). «Elementos y significados del malestar con la política. Un acercamiento cualitativo a partir de la indagación con grupos de discusión», 2011 CEO Barcelona.

Vitali S.; Glattfelder, J. B.; Battiston, S. (2011). «The Network of Global Corporate Control». Public Library of Science (octubre, 26). Disponible en: http://www. plosone.org/article/info\%3Adoi\%2F10.1371\%2Fjournal.pone.0025995

Wilson, O. E. (2012). La conquista social de la Tierra. Barcelona: Debate.

Zallo, R. (2011a). «Paradojas, retos y políticas en el inicio de la era digital». III Congreso Internacional Latina de Comunicación Social. Universidad de La Laguna, Diciembre 2011. Disponible en: http://www.revistalatinacs.org/11SLCS/ actas_2011_IIICILCS/Zallo.pdf

Zallo, R.(2011b). Estructuras de la comunicación y de la cultura. Políticas en la era digital. Barcelona: Gedisa. 


\section{Referencia de este artículo}

Zallo Elguezabal, Ramón (2013). Comunicación y democracia en el entorno digital. En: adComunica. Revista Científica de Estrategias, Tendencias e Innovación en Comunicación, $\mathrm{n}^{\circ} 5$. Castellón: Asociación para el Desarrollo de la Comunicación adComunica, Universidad Complutense de Madrid y Universitat Jaume I, 141-174. DOI: http://dx.doi.org/10.6035/2174-0992.2012.4.10. 